\title{
PERFORMANCE AND MEAT ATTRIBUTES OF CHICKENS REARED ON DEEP LITTER AND FREE RANGE
}

\author{
RENDIMIENTO Y ATRIBUTOS DE LA CARNE DE POLLOS \\ CRIADOS EN CAMA PROFUNDA Y AL AIRE LIBRE
}

Sogunle, O.M. ${ }^{1 *}$, Olaniyi, O.A. ${ }^{1}$, Shittu, T.A. ${ }^{2}$ and Abiola, S.S. ${ }^{1}$

'Department of Animal Production and Health. University of Agriculture. Abeokuta. Ogun State. Nigeria. *jidesogunle@yahoo.com; sogunleom@unaab.edu.ng

${ }^{2}$ Department of Food Science and Technology. University of Agriculture. Abeokuta. Ogun State. Nigeria.

\section{AdDiTIONAL KEYWORDS}

Boiled meat. Grilled meat. Production system.

\section{SUMMARY}

This study was carried out on the performance and meat sensory attributes of 150 cockerel chickens each of Harco Black and Novogen strains reared on deep litter and free range production systems. The birds were brooded for 4 weeks and thereafter allotted to the different production systems for a period of 12 weeks. Each production system was allotted 150 chicks (75 chicks per strain) with three replicates of 25 chicks. The birds on deep litter production system were fed ad libitum while each bird on free range was fed $50 \%$ of its daily feed requirement. On the $84^{\text {th }}$ day, a total of 36 birds were randomly selected for slaughtering by neck decapitation and the sensory attributes of the meat were determined. The data generated were subjected to a two-way analysis of variance in a $2 \times 2$ factorial experimental arrangement. Novogen strain on free range consumed less feed $(p<0.05)$ and had the best feed: gain ratio $(2.72)$. The results showed that the production systems and strains gave similar results by factors though higher percentage mortality was recorded in birds reared on free range. Novogen strain on free range recorded the highest $(p<0.05)$ value of $38 \%$ in mortality while Harco Black on deep litter recorded the least value $(6 \%)$. Significant $(p<0.05)$ differences were found in the taste and flavour of grilled cockerel meat with Novogen strain on free range having the highest values of 8.00 and 7.50 , respectively. Conclusively, for better meat sensory attributes, birds should be reared on free range.

\section{Palabras claVe adicionales}

Carne cocida. Carne a la parrilla. Sistema de producción.

\section{RESUMEN}

Se consideró el rendimiento y atributos sensoriales de la carne de 150 pollos de las lineas Harco Black y Novogen explotados en sistemas de cama profunda y a campo. Las aves, tras 4 semanas de acostumbramiento fueron asignadas a los diferentes sistemas de producción durante un período de 12 semanas. A cada sistema de producción se destinaron 150 pollos (75 por línea), con tres repeticiones de 25 pollos. Las aves en el sistema de cama profunda fueron alimentadas ad libitum; a las aves criadas a campo se les suministró el $50 \%$ de sus necesidades de alimentación diaria. En el día 84, un total de 36 aves fueron seleccionadas al azar para el sacrificio por decapitación y determinar los atributos sensoriales de la carne. Los datos generados se sometieron a un análisis de la varianza de dos vías en un diseño factorial $2 \times 2$. Las aves de la línea Novogen en pastoreo consumieron menos pienso $(p<0,05)$ y presentaron el mejor índice de transformación $(2,72)$. Los resultados tanto por sistemas de producción como por líneas, fueron similares aunque el porcentaje de mortalidad fue más alto en las aves criadas en pastoreo. La línea Novogen en pastoreo registró el más alto $(p<0,05)$ valor de mortalidad $(38 \%)$, mientras que la línea Harco Black en cama profunda registró el menor valor (6\%). Se encontraron diferencias significativas $(p<0,05)$ en el gusto y el aroma de la carne a la parrilla con la línea Novogen en campo abierto que presentaron los valores más altos ( 8,00 y 7,50 , respectivamente). En conclu- 
sión, la cria a campo de las aves proporciona los mejores atributos sensoriales de la carne.

\section{INTRODUCTION}

The increased emphasis on regulation has driven changes on how animals are fed and managed will continue, possibly in an accelerated manner with much pressure on reducing costs to increase supply through the use of larger and more integrated facilities (McWilliams, 1993) in a sustainable production system. In sustainable poultry production, Appleby et al. (1992) opined alternatives to confinement housing and cages, such as access to range which is considered an environmentally sound and economically viable approach. The free range production system focuses on lowinput strategies and support of rural communities by maintaining the family farm. Traditionally, researches are focused on nutrition; hence, much information is available on effect of different energy and protein intakes (Macleod, 1990) but not much documentation on the attendant effects of free range production system on the performance and meat sensory attributes of cockerels. Free range production can reduce stress and increase comfort and bird welfare, thereby leading to products with better taste and flavour compared to conventionally produced broiler chicken (Fanatico et al., 2006).

Cockerel rearing has attained great importance due to its hardiness and relatively high survival rate, though its production does not appear profitable due to its relatively long maturity period. However, it is well documented (Okosun, 1987) that its live weight increases with age unlike in spent hens in which the live weight decreases with increasing egg production and then age. Housing may not be provided (Kuit et al., 1986; Atunbi and Sonaiya, 1994) and where this is done, usually local materials are used for construction (Atunbi and Sonaiya, 1994). The feed resources vary depending on local conditions and the farming system. Management is minimal with some variations of gender roles in the activities (Olayiwole, 1984; Achiempong, 1992). However, the health of the birds is not guaranteed because there are no disease control programmes (Yongolo, 1996).

Although the present poultry industry offers affordable products, many farmers are interested in alternative poultry production system of which the free range is the option particularly in meeting the growing demand for meat and eggs produced by birds that are allowed to express their natural behavior. Little research has been published on rural poultry production, despite the fact that $80 \%$ of the poultry population in Africa is kept by the households in their 'backyard' (Permin, 1997; Kitalyi, 1998). The free range system was adopted to harvest the advantages of increasing the comfort and enhancing the birds' welfare as well as eliminate routine medication and waste disposal problems. In addition, the strains of cockerels that were used included the common Harco Black cockerel (2011) and a novel strain Novogen cockerel (2011) for a comparative study of their performance and meat sensory attributes.

\section{MATERIALSAND METHODS}

\section{DESCRIPTION OF EXPERIMENTAL SITE}

The study was carried out from April, 2010 to August, 2010 at specialized farm in Odeda Local Government Area of Ogun State, Nigeria located at an altitude of $169 \mathrm{~m}$, latitude $7^{\circ} 10^{\prime} 50^{\prime \prime} \mathrm{N}$ and longitude $3^{\circ} 26^{\prime} 37^{\prime \prime}$ E. The sensory analysis was carried out at the Sensory Laboratory of Food Science and Technology Department, College of Food Science and Human Economics (COLFHEC), University of Agriculture, Abeokuta.

\section{EXPERIMENTAL BIRDS AND MANAGEMENT}

A total of 300, day-old cockerel chicks from two strains (Harco Black and Novogen) 


\section{CHICKENS BRED ON DEEP LITTER AND FREE RANGE: PERFORMANCE AND MEAT}

were used for the study. The birds were sourced from Avian Specialties Ltd, Ibadan, Oyo State, Nigeria. The birds were vaccinated for four weeks before the inception of the experiment after which no vaccination and medication were employed. The birds were differentiated on strain basis (150 birds of Harco Black and150 birds Novogen strains, respectively). These were further divided into twelve replicates of 25 birds each using coloured numbered rings for identification. In other words, there were 75 birds each of Harco Black and Novogen in either deep litter or free range which were further divided into three replicates, respectively.

\section{HOUSING}

The birds were brooded on deep litter for 4 weeks in confinement. Thereafter, 150 chicks were left to roam freely for the remaining 12 weeks of the study on 727.27 $\mathrm{m}^{2}$ of land with a floor space of $4.84 \mathrm{~m}^{2} / \mathrm{bird}$ while the other 150 chicks were wholly confined for the period of the experiment on a floor space of about $0.25 \mathrm{~m}^{2} /$ bird and an average light hours of about $12 \mathrm{hrs} /$ day. In the free range system, a mini-shelter with provision for perching of the birds was constructed on the site to protect the birds from rain and allow the birds to exhibit their natural behaviour.

\section{EXPERIMENTALDIET}

The birds on range grazed on pasture which was supplemented on daily basis with a calculated ration containing $17 \% \mathrm{CP}$ and 13.34 ME KJ/kg. Each bird on free range was maintained on $50 \%(24 \mathrm{~g} / \mathrm{b} / \mathrm{d})$ of its daily feed requirement of about $48 \mathrm{~g} / \mathrm{b} / \mathrm{d}$ for 12 weeks of the experiment. However, birds managed in deep litter were given feed of the same nutrient and water ad libitum. The birds on free range had access to the following Scavengeable Feed Resource Base (SFRB): household cooking waste, cereal and cereal by-products, vegetable weed particularly Talinum triangulare, shrubs, sedges and grasses (including Platostoma africanum, Momordica charantia Linn, Heliotropium indicum Linn, Cyperus iria Linn, Eragrostis tenella and Eleusine indica Graertn), animal proteins (maggots and earthworms) and commercially prepared diet.

As described by Roberts (1999) and enunciated by Sonaiya et al. (2002) the value of the SFRB was estimated by weighing the amount of daily feed product/household waste generated by each of twelve (12) families around the experimental site as parameter ' $\mathrm{H}$ ' divided by the proportion of feed product/household waste found in the crop of the scavenging birds (assessed visually) as parameter ' $p$ ' and multiplied by the percentage of household $(66.67 \%)$ that kept chickens 'c'. The formula used was:

$\mathrm{SFRB}=\mathrm{H} / \mathrm{p}^{*} \mathrm{C}$

The average daily household leftover available for birds on the range was 123.27 $\mathrm{g} / \mathrm{d}$ and the SFRB was $35.83 \mathrm{~g} / \mathrm{b} / \mathrm{d}$ including the supplemented diet.

\section{Performance characteristics}

The birds were weighed at the beginning of the experiment ( $4^{\text {th }}$ week of age $)$ and then weighed on a weekly basis. Birds were weighed in the morning before given feed and water. Birds on total confinement were fed ad libitum, while those on range were fed only in the morning.

\section{SensoryeVALUATION}

Seven experienced panelist from Department of Food Science and Technology, College of Food Science and Human Economics (COLFHEC) University of Agriculture, Abeokuta were used for the sensory evaluation of boiled and grilled meat samples from the breast muscle. Samples were washed individually in clean water, packed in a transparent double layer polythene bag and tagged for identification.

Thereafter, they were boiled in water for 
30 minutes and other parts were grilled in a microwave oven for about 20 minutes and were allowed to cool under room temperature and served to a panel of 7 assessors previously trained in basic organoleptic assessment procedure. Each panelist was required to masticate one sample per treatment with ranked preferences in the following categories: colour, taste, texture and flavor. A nine-point hedonic scale was used, 1 referring to extremely dislike, and 9 as extremely like.

\section{STATISTICAL ANALYSIS}

The data generated were subjected to a two-way analysis of variance in a $2 \times 2$ factorial experimental arrangement. Significantly $(\mathrm{p}<0.05)$ different means were separated using Duncan's Multiple Range Test as contained in SAS (1999) package.

$$
Y_{i j k}=\mu+A_{i}+B_{j}+(A B)_{i j}+\varepsilon_{i j k}
$$

where:

$\mathrm{Y}_{\mathrm{ijk}}=$ individual observation,

$\mu=$ general mean,

$A_{i}=$ effect of factor $A$ (housing),

$B=$ effect of factor $B$ (strain),

$(A B)_{i j}=$ effect of interaction AB (housing ${ }^{*}$ strain), $\varepsilon_{\mathrm{ijk}}=$ experimental error.

\section{RESULTS}

In the main effect of production system and strain on the performance of cockerel chickens (table I) significant $(\mathrm{p}<0.05)$ differences were obtained in the feed intake and the mortality (\%). A higher mortality (70 $\%)$ value was recorded in birds raised on free range. Also, the feed intake and the mortality were significantly $(\mathrm{p}<0.05)$ affected by the strain. Novogen strain recorded a lower feed intake $(37.15 \mathrm{~g} / \mathrm{b} / \mathrm{d})$ and a higher mortality $(52 \%)$ values when compared to the values obtained in Harco Black strain of cockerels.

In the figure 1, it could be observed that the performance in terms of weight gain of Novogen strain of cockerel on deep litter production system was better when compared to those on free range. This finding was corroborated by the rate of change of weight of Harco Black strain of cockerel chicken in the two production systems.

The main effect of production system and strain on the sensory analysis of boiled and grilled cockerel chickens is presented in table II. The production system influenced $(\mathrm{p}<0.05)$ the taste and flavor of the grilled chicken with birds on free range having higher values. Birds managed on deep litter had the least values of 6.25 for taste and flavour, respectively.

\section{DISCUSSION}

The result of the performance of birds in

Table I. Main effect of production system and strain $( \pm S E)$ on the performance of cockerel chickens. (Principal efecto del sistema de producción y línea ( $\pm \mathrm{SE}$ ) sobre el rendimiento de pollos).

\begin{tabular}{lcccc}
\hline & \multicolumn{2}{c}{ Production system } & \multicolumn{2}{c}{ Strain } \\
& Deep litter & Free range & Harco Black & Novogen \\
& & & & \\
\hline Initial weight $(\mathrm{g})$ & $173.33 \pm 6.67$ & $176.67 \pm 5.58$ & $168.33 \pm 7.03$ & $181.67 \pm 3.07$ \\
Final weight $(\mathrm{g})$ & $1345.00 \pm 37.93$ & $1250.00 \pm 34.16$ & $1295.00 \pm 47.87$ & $1300.00 \pm 34.83$ \\
Weight gain $(\mathrm{g} / \mathrm{b} / \mathrm{d})$ & $13.93 \pm 0.40$ & $12.48 \pm 0.44$ & $13.41 \pm 0.55$ & $13.31 \pm 0.43$ \\
Feed intake $(\mathrm{g} / \mathrm{b} / \mathrm{d})$ & $42.45 \pm 1.30^{\mathrm{a}}$ & $35.83 \pm 0.76^{\mathrm{b}}$ & $41.13 \pm 4.29^{\mathrm{a}}$ & $37.15 \pm 3.45^{\mathrm{b}}$ \\
Feed: gain & $3.05 \pm 0.11$ & $2.82 \pm 0.10$ & $3.08 \pm 0.31$ & $2.79 \pm 0.18$ \\
Mortality $(\%)$ & $20.00 \pm 1.32^{\mathrm{b}}$ & $70.00 \pm 6.17^{\mathrm{a}}$ & $38.00 \pm 4.11^{\mathrm{b}}$ & $52.00 \pm 3.14^{\mathrm{a}}$ \\
\hline
\end{tabular}

abcdMeans in the same row by factor with different superscripts differ significantly $(p<0.05)$. 


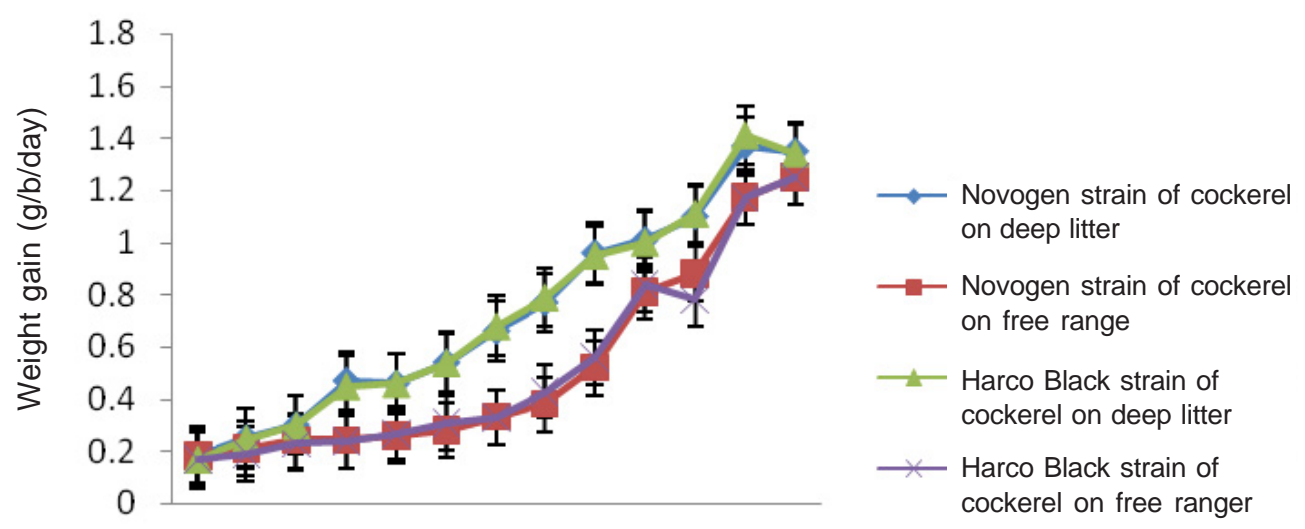

$\begin{array}{lllllllllllll}1 & 2 & 3 & 4 & 5 & 6 & 7 & 8 & 9 & 10 & 11 & 12 & 13\end{array}$

Weeks

Figure 1. Rate of change of weight of Novogen and Harco Black strains of cockerels on deep litter and free range production systems. (Cambios de peso de las líneas Novogen y Harco Black criadas en cama profunda o a campo).

deep litter and free range systems in terms of final weight, and average daily gains showed no significant effect. The findings support those of Fanatico et al. (2005) who reported no differences in the carcass yield of indoor and outdoor birds. Similarly, when comparing the deep litter system and those on free range system, Benyi and Habi (1998) reported that feed restriction had no significant effect on body weight and growth rate in chickens. In general, productive performance according to production systems

Table II. Main effect of production system $( \pm S E)$ and strain $( \pm S E)$ on the sensory analysis of boiled and grilled cockerel chickens ( 9 samples per production system per strain). (Principal efecto del sistema de producción $( \pm S E)$ y línea $( \pm S E)$ sobre el análisis sensorial de la carne de pollo hervida o a la parrilla. Nueve muestras por sistema de producción y línea).

\begin{tabular}{lcccc}
\hline & \multicolumn{2}{c}{ Production system } & \multicolumn{2}{c}{ Strain } \\
& Deep litter & Free range & Harco Black & Novogen \\
\hline Boiled cockerel chicken & & & & \\
Colour & $6.75 \pm 0.24$ & $6.58 \pm 0.20$ & $6.50 \pm 0.23$ & $6.83 \pm 0.21$ \\
Taste & $6.58 \pm 0.48$ & $6.17 \pm 0.36$ & $6.42 \pm 0.40$ & $6.33 \pm 0.44$ \\
Texture & $6.83 \pm 0.23$ & $6.92 \pm 0.31$ & $6.83 \pm 0.28$ & $6.92 \pm 0.27$ \\
Flavour & $6.25 \pm 0.31$ & $6.33 \pm 0.42$ & $6.25 \pm 0.33$ & $6.33 \pm 0.40$ \\
Grilled cockerel chicken & & & & \\
Colour & $7.42 \pm 0.31$ & $7.58 \pm 0.23$ & $7.33 \pm 0.27$ & $7.67 \pm 0.27$ \\
Taste & $6.25 \pm 0.54^{\mathrm{b}}$ & $7.67 \pm 0.31^{\mathrm{a}}$ & $6.42 \pm 0.54$ & $7.50 \pm 0.38$ \\
Texture & $7.42 \pm 0.29$ & $7.17 \pm 0.23$ & $7.25 \pm 0.26$ & $7.33 \pm 0.27$ \\
Flavour & $6.25 \pm 0.38^{\mathrm{b}}$ & $7.50 \pm 0.25^{\mathrm{a}}$ & $6.50 \pm 0.42$ & $7.25 \pm 0.26$ \\
\hline
\end{tabular}

abMeans in the same row by factor with different superscripts differ significantly $(p<0.05)$. 
was in descending order for birds in deep litter and free range systems. The reduced feed intake of birds on free range showed that intake of the birds on free range was being controlled by their requirements. The birds' performance reported corroborates the findings by Bockish et al. (1999) that the stress such as temperature, relative humidity and sun radiation in indoor and grass paddock are important indices of environment responsible for animal performance.

Gordon and Charles (2002) reported that temperature and photoperiod have the potential to influence growth mainly by affecting feed intake. Novogen strain performed better on both deep litter and free range than Harco Black although measurements were not statistically significant. The production system affect the mortality rate as birds managed on free range had a higher mortality. This might be due to the age at which birds were introduced to the field and cold weather.

The capacity of a panel to discriminate meat from different genotypes was largely debated and many authors have reported interactions and not unequivocal results (Farmer et al., 1997). In this study, the production systems and the strains had no effect on the sensory analysis of the cooked chicken. This was similar to Garcia et al. (1995) who did not notice any difference in sensory traits of capon meat reared in indoor or outdoor system. Also, the authors reported no differences in aroma of cooked meat of breast and thigh in capons. This was in contrast to the findings of Girolami et al. (2003), who reported that the differences in meat tenderness were detected by the sensory panel, whereas instrumental measures were not able to detect any difference. Although, tenderness is usually thought to be the most important organoleptic attribute of meat (Seabra et al., 2001), panelist classified meat from birds that are in confinement with the highest values for colour and taste while birds on free range had highest value for texture and flavor.
Though this was expected, it was possible that different leguminous species may result in different flavors and therefore different sensory attributes (Gordon and Charles, 2002). Chemical reactions during cooking released many substances, such as volatile compounds, that give aroma and flavor to the meat (Aliani and Farmer, 2005). The authors also reported that these attributes could be particularly affected by the concentrations of lipids and other compounds of raw meat, such as reduced and phosphorylated sugars, amino acids, and thiamine. The natural components had little aroma until they interacted during cooking; the reactions included lipid oxidation, the thermal degradation of thiamine, and the Maillard reaction between amino compounds (amine, amino acid, peptide, or protein) and a carbonyl compound (Aliani and Farmer, 2005).

The production systems had effect on taste and flavour of grilled meat with birds on free range having a higher value compared with those on deep litter. It is known that the temperature variation and profile during processing affect the physical, chemical and sensory qualities of food. The temperature regime during the grilling process could account for the perceived difference in the sensory characteristics (Chen and Ramaswamy, 2002). Moritz et al. (2005) also indicated that forage intake had very little influence on meat texture for free range chickens. However, current consumers in many places preferred meat from animals reared outdoors to those reared indoors, although they do not recognize differences in meat sensory traits (Fanatico et al., 2007).

\section{CONCLUSION}

The performance of birds on free range was less than that recorded for birds on deep litter.

The production system influenced the taste and flavor of the grilled chicken with 


\section{CHICKENS BRED ON DEEP LITTER AND FREE RANGE: PERFORMANCE AND MEAT}

birds on free range having higher values.

\section{RECOMMENDATIONS}

Free range production system should be encouraged for enhanced meat sensory attributes.

\section{REFERENCES}

Achiempong, C.K. 1992. Women in poultry keeping for sustainability in Ghana. In: Proceedings, $19^{\text {th }}$ World Poultry Congress. 20-24 September. Amsterdam. The Netherlands. pp. 71-78.

Aliani, M. and Farmer, L.J. 2005. Precursors of chicken flavor. I. Determination of some flavor precursors in chicken muscle. J Agr Food Chem, 53: 6067-6072.

Appleby, M.C., Barry, O.H. and Elson, H.A. 1992. Poultry systems: Behaviour, management and welfare. CAB International. Wallingford. UK. $238 \mathrm{pp}$.

Atunbi, O.A. and Sonaiya, E.B. 1994. An assessment of backyard poultry housing in Osogbo, Osun State, Nigeria. African Network for Rural Development Newsletter, 4: 7.

Benyi, K. and Habi, H. 1998. Effect of feed restriction during finishing period on the performance of broiler chickens. Brit Poultry Sci, 39: 423-425.

Bockish, F.T., Jungbluth, T. and Rudovsky, A. 1999. Technical indicators for evaluation of housing systems for cattle, pigs and laying hens relating to animal welfare. Zuchtungskunde, 71: 38-63.

Chen, C.R. and Ramaswamy, H.S. 2002. Modeling and optimization of variable retort temperature thermal processing using coupled neural networks and genetic algorithms. J Food Eng, 53: 209-220.

Fanatico, A.C., Pillai, P.B., Cavitt, L.C., Owens, C.M. and Emmert, J.L. 2005. Evaluation of slower growing broiler genotypes grown with and without outdoor access: growth performance and carcass yield. Poultry Sci, 84: 13211327.

Fanatico, A.C., Pillai, P.B., Cavitt, L.C., Emmert, J.L., Meullenet, J.F. and Owens, C.M. 2006. Evaluation of slow-growing broiler genotypes grown with and without outdoor access: sensory attributes.

\section{ACKNOWLEDGEMENT}

The authors gratefully acknowledged the Institute of Food Security, Environmental Resources and Research (IFSERAR) of the University of Agriculture, Abeokuta, for providing the aids-in-grant for the study.

Poultry Sci, 85: 337-343.

Fanatico, A.C., Pillai, P.B., Emmert, J.L., Gbur, E.E., Muellenet, J.F. and Owens, C.M. 2007. Sensory attributes of slow and fastgrowing chicken genotypes raised indoors or with outdoors access. Poultry Sci, 86: 2441-2447.

Farmer, L.J., Perry, G.C., Lewis, P.D., Nute, G.R., Piggot, J.R. and Patterson, R.L.S. 1997. Responses of two genotypes of chicken to the diets and stocking densities of conventional UK and Label Rouge production systems. II. Sensory attributes. Meat Sci, 47: 77-93.

Garcia, M., Cepero, R., Campo, M.M., Lafuente, R., Sañudo, C. and Canti, M. 1995. Effects of production system on the quality of label chickens and capons. Proceedings of the $12^{\text {th }}$ European Symposium on the Quality of Poultry Meat. Zaragoza. España. pp. 207-212.

Girolami, A., Marsico, I., D'Andrea, G., Brughieri, A., Napoletano, F. and Cifuni, G.F. 2003. Fatty acid profile, cholesterol content and tenderness of ostrich meat as influenced by age at slaughter and muscle type. Meat Sci, 64: 309-315.

Gordon, S.H. and Charles, D.R. 2002. Niche and organic chicken products. Nottingham Univ. Press. Nottingham. UK.

Harco black strain. 2011. http://www.babolnatetra. com/termekek_en.html (14/10/2011).

Novogen strain. 2011. http://www.novogenlayer.com/managementguides/index.php?id=22 (14/10/2011).

Kitalyi, A.J. 1998. Village chicken production systems in rural Africa-Household food security and gender issues. FAO Animal Production and Health Paper 142. Publishing Management Group. FAO Information Division. pp. 86.

Kuit, H.G., Traore, A. and Wilson, R.T. 1986. Livestock production in Central Mali: Ownership, management and productivity of poultry in traditional sector. Trop Anim Health 


\section{SOGUNLE, OLANIYI, SHITTU AND ABIOLA}

Pro, 18: 222-231.

Macleod, M.G. 1990. Energy and nitrogen intake expenditure and retention at $200 \mathrm{C}$ in growing fowl given diets with a range of energy and protein contents. Brit $J$ Nutr, 64: 625-637.

McWilliams, J. 1993. Chickens in the garden: possibilities in pest control. Countryside and Small Stock Journal, (Sep-Oct): 28-29.

Moritz, J.S., Parsons, A.S., Buchanan, N.P., Baker, N.J., Jaczynski, J., Gekara, O.J. and Bryan, W.B. 2005. Synthetic methionine, organic compound, one of the 20 amino acids commonly found in animal proteins. Only the L-stereoisomer appears in mammalian protein and feed restriction effects on performance and meat quality of organically reared broiler chickens. $J$ Appl Poultry Res, 14: 521-535.

Okosun, S.E. 1987. Studies on calorie and protein requirements of cockerels. Ph.D. Thesis. University of Ibadan. Ibadan. Nigeria. pp. 21-35.

Olayiwole, C.B. 1984. Rural women's participation in agricultural activities: implication for training extension home economists. DAl, 45: 1223.

Permin, A. 1997. Helminths and helminthosis in poultry with special emphasis on Ascaridia galli in chickens. Ph.D Thesis. The Royal
Veterinary and Agricultural University. Copenhagen. Denmark. 119 pp.

Roberts, J.A. 1999. The scavenging feed resource base in assessment of the productivity of scavenging chickens. In: Spradbrow, P.B. (Ed.). Newcastle disease in village chickens-control with thermostable oral vaccine. ACIAR Proceedings № 39. Canberra. Australia. pp. 29-32. SAS. 1999. Version 8. SAS. Institute Inc. Cary NC. USA.

Seabra, L.M., Zapata, J.F., Fuentes, M.F., Aguiar, C.M, Freitas, E.R. and Rodrigues, M.C. 2001. Effect of deboning time, muscle tensioning and calcium chloride marination on texture characteristics of chicken breast meat. Poultry Sci, 80: 109-112.

Sonaiya, E.B., Dazogbo, J.S. and Olukosi, O.A. 2002. Further assessment of scavengeable feed resource base. In: Characteristics and parameters of family poultry production in Africa. Results of a FAO/IEA Coordinated Research Program. IAEA. Vienna. Austria. pp. 193-200.

Yongolo, M.G.S. 1996. Epidemiology of Newcastle disease in village chickens in Tanzania. MVM dissertation. Sokoine University of Agriculture. Morogoro. Tanzania. 234 pp. 